\title{
Dynamics of Kudoa camarguensis (myxosporean) infection in two gobiid species, Pomatoschistus microps and $P$. minutus (Teleostei: Pisces), in the Rhône River delta, France
}

\author{
C. Pampoulie* \\ Station Biologique de la Tour du Valat, Le Sambuc, 13200 Arles, France, and Laboratoire Ecosystèmes Lagunaires, UMR 5119, \\ Université Montpellier II, Sciences et Techniques du Languedoc, Place Eugène Bataillon, 34095 Montpellier Cedex 5, France
}

\begin{abstract}
The occurrence of the myxosporean parasite Kudoa camarguensis was surveyed monthly during 1997 in a brackish-water lagoon of the Rhône River delta (France). $K$. camarguensis was found on its typical host, Pomatoschistus microps, and on an additional host, $P$. minutus. Prevalence and mean abundance were higher in the typical host than in the additional host due to differences in the temporal occupancy of the lagoon by the 2 species. The temporal occurrence of this myxosporean parasite is discussed in relation to the migratory habits of $P$. minutus and the sedentary habits of P. microps.
\end{abstract}

KEY WORDS: Myxosporean parasite - Kudoa camarguensis · Goby migration $\cdot$ Spawning strategy

Resale or republication not permitted without written consent of the publisher

The myxosporean parasite Kudoa camarguensis Pampoulie et al. 1999 has been found on its type host Pomatoschistus microps (Krøyer, 1838), and on its additional host $P$. minutus (Pallas, 1770) (Pampoulie et al. 1999a), 2 gobies that inhabit Mediterranean lagoons. This parasite, which has been recorded exclusively from the Rhône delta (southern France), infects muscle tissue, especially the abdominal wall, causing liquefaction in less than $1 \mathrm{~h}$ after death of infected fish (Pampoulie et al. 1998). Several studies have dealt with the economic impact of myxosporean parasites, which are generally observed in fish from commercial farms (Paperna 1982, Kent et al. 1994), with Kudoa spp. infections occurring in the muscle of economically important fish such as tilapias (Gbankoto et al. 2001a,b) and salmon (St-Hilaire et al. 1998). K. camar-

${ }^{*}$ Present address: KU Leuven, Laboratory of Aquatic Ecology, Charles de Bériotstraat 32, 3000 Leuven, Belgium.

E-mail: pampoulie@univ-montp2.fr guensis infects wild, non-commercial fish, with different survival strategies, that occupy lagoons. In the Malagroy lagoon, $P$. microps and $P$. minutus are annual species and repeat-spawners. The former reproduces in the lagoon during spring (Pampoulie et al. 2000), whereas the latter migrates from the lagoon to the open sea to spawn in winter (Pampoulie et al. 1999b). Throughout the year, the size distribution of these fishes indicates that their populations are represented by a single cohort (Pampoulie 1999). In July and August adult $P$. microps die, and recruitment of youngof-the-year (YOY) occurs (Pampoulie et al. 2000); $P$. minutus undergoes the same process in March and April (Pampoulie et al. 1999b). My 1997 data thus monitored the impact of the parasite on 1 cohort and contribute to the knowledge of $K$. camarguensis distribution dynamics in the Rhône delta. The aim of this work was (1) to describe the pattern of infection of $K$. camarguensis in a sedentary ( $P$. microps) and a migratory $(P$. minutus) goby species, and (2) to consider the possible impact of this myxosporean parasite on its hosts.

Materials and methods. In 1997, monthly sampling took place from January to December in the Malagroy lagoon (Rhône delta, France), with a fyke net $(6 \mathrm{~mm}$ mesh size) set on 5 consecutive days per month. The Malagroy is a Mediterranean lagoon belonging to the large Vaccarès lagoon complex which covers 11000 ha. Its average depth and salinity are $1 \mathrm{~m}$ and $19.9 \mathrm{~g} \mathrm{l}^{-1}$, respectively, and its connection with the sea is regulated by sluices in the sea dyke (Chauvelon et al. 1999).

Gobies were preserved in $10 \%$ formalin. To ensure that all monthly samples were of comparable total length, fish belonging to the same size range were grouped into $2 \mathrm{~mm}$ size classes for Pomatoschistus 
microps and $4 \mathrm{~mm}$ for P. minutus. A minimum of 5 fish per size class was examined. Plasmodia of Kudoa camarguensis were counted under a dissecting microscope. The parasitological indices used to document the monthly status of the host-parasite system were
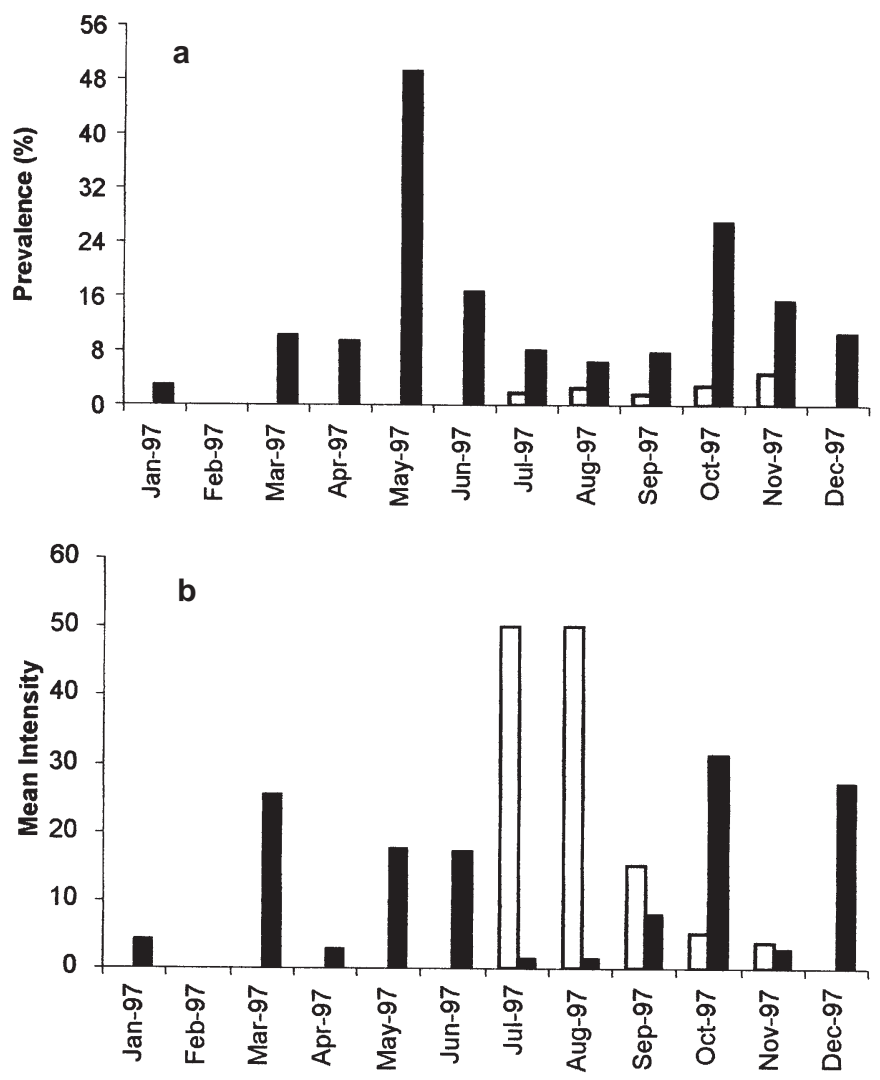

Life cycle of the hosts

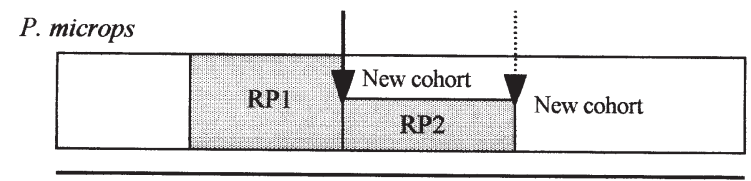

P. minutus
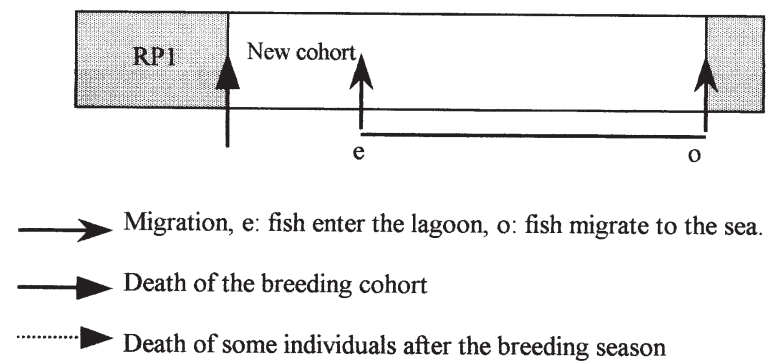

Fig. 1. Kudoa carmarguensis. (a) Prevalence and (b) mean intensity of parasite on the hosts Pomatoschistus microps (black bars) and $P$. minutus (white bars) in the Malagroy lagoon, Rhône River delta. Life cycle of the hosts is also shown (RP1, RP2: first and second reproductive periods, respectively) prevalence and mean intensity as defined by Margolis et al. (1982).

Results. Of 811 individuals of Pomatoschistus microps examined, 102 were infected with Kudoa camarguensis, whereas of the 495 P. minutus individuals examined, only 10 were infected. Monthly prevalence (Fig.1) varied from 0 to $49.23 \%$ for P. microps and from 0 to $4.76 \%$ for $P$. minutus; mean intensity varied from 0 to 31.29 and 0 to 50.00, respectively. Prevalence and mean intensity peaked in May and October for $P$. microps, while for $P$. minutus prevalence peaked in November and intensity in July (Fig. 1). YOY of this species entering the lagoon in June were not infected. The frequency distribution of $K$. camarguensis on $P$. microps fitted a negative binomial distribution (Kolmogorov-Smirnov test, $\mathrm{p}<0.05)$. The aggregation coefficients were $k=0.18$ and $k=0.10$ with means (m) of 52.38 and 104.45 for males and females, respectively. $P$. minutus was not tested in this respect, as very few individuals were infected.

Discussion. The prevalence of Kudoa camarguensis on brackish-water Pomatoschistus microps was higher than the frequencies of Kudoa sp. on flounder from the lagoon of Venice (Pellizatto \& Canzonier 1985), but lower than the frequencies reported for 2 species of hake in the marine environment (Kabata \& Whitaker 1986, Sardella et al. 1987). Its frequency on $P$. minutus was close to that in the lagoon of Venice. P. minutus spends part of the year (from February to May/June) in the sea during the breeding season (Bouchereau et al. 1991, Pampoulie et al. 1999b), but in 1997 YOY entering the Rhône delta lagoon were not infected. This suggests that $K$. camarguensis infections originate in brackish-waters and that $P$. minutus comes into contact with the parasite in the lagoon and not the sea. This was confirmed by the large size of the infected P. minutus individuals and the prevalence of the parasite, which increased from June to November. The greater the fish density in the lagoon, the higher the number infected.

Pomatoschistus microps was present in the lagoon throughout the year; YOY occurred in June and July, while the parent individuals did not survive the reproductive effort (Pampoulie 1999, Pampoulie et al. 2000). These YOY spawned from July to September (Fig. 1: RP2), becoming increasingly infected over time, until up to $10 \%$ of the population were infected in September. Some individuals died during the breeding season (Pampoulie et al. 2000), resulting in variations in the prevalence values from June to September.

Basically, the difference in the prevalence between these 2 species could result from 3 main factors: (1) differential immunity between the 2 species; (2) differences in their temporal and spatial occupancy of the lagoon; (3) specificity of Kudoa camarguensis. 
There is no information available on the possible differential immunity of these 2 species. Further investigations need to be carried out to test this factor, whereby it will be necessary to examine the life cycle of Kudoa camarguensis.

The difference in the temporal and spatial occupancy of this Mediterranean lagoon by these 2 species (described by Bouchereau 1997a,b and Pampoulie 1999), could well be responsible for the observed difference in infection. Pomatoschistus microps is present year-round in the lagoon, while $P$. minutus enters the lagoon from June to December, and then undertakes a spawning migration to the open sea, where it remains until the death of the breeding individuals in the following June. Based on their different temporal occupancies of the lagoon, differences in the prevalence of the parasite on these 2 gobies are to be expected. P. minutus entering the lagoon in June were not infected; they probably became infected as soon as they entered the lagoon. It is not known what happens to the parasites released into the marine environment by $P$. minutus when these die after reproduction. They could be sources of infection for marine species since, in some cases, transmissions can occur from fish-to-fish (Diamant 1997). Further investigations on this Mediterranean myxosporean parasite are necessary, especially in closely related marine species of gobies.

The differences in prevalence could also be due to the incapacity of Kudoa camarguensis to develop in Pomatoschistus minutus, which is not a typical host of this myxosporean parasite. These 2 goby species are not really phylogenetically closely related (Wallis \& Beardmore 1984), having diverged a long time ago. This, combined with the difference in their temporal occupancy of the lagoon, could explain why K. camarguensis did not develop well on $P$. minutus.

This study has shown that differences in the temporal occupancy of an environment can induce changes in the infection pattern of a parasite such as Kudoa camarguensis. The possible release of the parasites into the sea still remains an open question. Recent studies have demonstrated that myxosporean parasites may affect host fecundity and survival (Adlerstein \& Dorn 1998). Thus, further field and experimental investigations should be carried out on this host-parasite system, especially in regard to Pomatoschistus minutus.

Acknowledgements. This work was funded by the Biological Station of Tour du Valat within a framework of a CIFRE agreement between the Laboratoire Ecosystèmes Lagunaires and the Tour du Valat. Special thanks are given to Dr A. J. Crivelli and Dr E. Rosecchi for their useful comments, to Dr E. Coulet, who authorised me to sample fishes in the Malagroy lagoon, and to anonymous referees for their fruitful comments.

\section{LITERATURE CITED}

Alderstein SA, Dorn MW (1998) The effect of Kudoa paniformis infection on the reproductive effort of female Pacific hake. Can J Zool 76:2285-2289

Bouchereau JL (1997a) Biodiversity of tactics used by three Gobiidae (Pisces; Teleostei): Pomatoschistus minutus (Pallas, 1770), P. microps (Krøyer, 1838), Gobius niger Linnaeus, 1758, to survive in a Mediterranean lagoon environment. Oceanol Stud 2-3:153-170

Bouchereau JL (1997b) Comparison of life history strategies of three gobiidae Pomatoschistus minutus (Pallas, 1770), P. microps (Krøyer, 1838) Gobius niger Linneus, 1758, (Pisces, Teleostei) over their geographical range. Oceanol Studies 2-3:171-190

Bouchereau JL, Tomasini JA, Quignard JP, Joyeux JC (1991) Stratégies et tactiques de reproduction de Pomatoschistus microps (Krøyer, 1838) et de Pomatoschistus minutus (Pallas, 1770) (Pisces, Gobiidæ) dans le golfe du Lion. Nids, déterminisme de la sédentarité et de la migration. Cybium 15:315-346

Chauvelon P, Pampoulie C, Gelin A (1999) Impact de la gestion des échanges hydrauliques entre les étangs du système Vaccarès et la Méditerranée sur les abondances de deux espèces euryhalines: le gobie des sables, Pomatoschistus minutus et la crevette grise, Crangon crangon. Bull Soc Linn Bord 27:48-48

Diamant A (1997) Fish-to-fish transmission of a marine myxosporean. Dis Aquat Org 30:99-105

Gbankoto A, Pampoulie C, Marques A, Sakiti GN (2001a) Occurrence of myxosporean parasites in the gills of two tilapias species from the Lake Nokoué (Bénin, West Africa): effect of host size and sex, and seasonal patterns of infection. Dis Aquat Org 44:219-224

Gbankoto A, Pampoulie C, Marques A, Sakiti NG (2001b) Myxobolus dahomeyensis infection in ovaries of tilapia species from Benin (West Africa). J Fish Biol 58:883-886

Kabata Z, Whitaker DJ (1986) Distribution of two species of Kudoa (Myxozoa: Multivalvulida) in the offshore population of the Pacific hake, Merluccius productus (Ayres, 1855). Can J Zool 64:2103-2110

Kent ML, Margolis L, Whitaker DJ, Hoskins GE (1994) Review of myxosporea of importance in salmonid fisheries and aquaculture in British Columbia. Folia Parasitol (Ceske Budejovice) 41:27-37

Margolis L, Esch GW, Holmes JC, Kuris AM, Schad GA (1982) The use of ecological terms in parasitology (report of an ad hoc committee of the American Society of Parasitologists). J Parasitol 68:131-133

Pampoulie C (1999) Conséquences d'une arrivée massive d'eau douce sur la communauté de gobies (Téléostéens, Pisces) d'une lagune méditerranéenne: l'exemple de l'Etang du Vaccarès (Camargue, France). PhD thesis, University Montpellier II

Pampoulie C, Marques A, Rosecchi E, Crivelli AJ, Bouchereau JL (1998) First record of Kudoa (Myxosporea) in Pomatoschistus microps in the Rhône delta, France. J Fish Biol 53:893-896

Pampoulie C, Marques A, Rosecchi E, Crivelli AJ, Bouchereau JL (1999a) A new myxosporean parasite, Kudoa camarguensis n. sp. recorded on two goby species (Teleostei: Pisces) in the Rhône Delta (Mediterranean Sea, France). J Eukaryot Microbiol 46:304-310

Pampoulie C, Rosecchi E, Bouchereau JL, Crivelli AJ (1999b) Life history traits of Pomatoschistus minutus (Teleostei, Pisces) in the Rhône Delta, France. J Fish Biol 55:892-896 
Pampoulie C, Bouchereau JL, Rosecchi E, Poizat G, Crivelli AJ (2000) Annual variations in the reproductive traits of Pomatoschistus microps in a Mediterranean lagoon undergoing environmental changes: evidence of phenotypic plasticity. J Fish Biol 57:1441-1452

Paperna I (1982) Kudoa infection in the glomeruli, mesentery and peritoneum of cultured Sparus aurata L. J Fish Dis 5: 539-543

Pellizzato M, Canzonier WJ (1985) Segnalazione del parasita Kudoa (Protozoa; Myxosporida) in pesci piatti della laguna di Venezia. Oebalia 11:807-808

Editorial responsibility: Wolfgang Körting,

Hannover, Germany
Sardella NH, Trinchero JL, Manca EA (1987) Efectos del deterioro producodo por mixosporidios de la especie Kudoa rosenbushi en la musculatura de Merluccius hubbsi. Rev Investig Desar Pesq 7:105-112

St-Hilaire S, Ribble C, Whitaker DJ, Kent ML (1998) Prevalence of Kudoa thyrsites in sexually mature and immature pen-reared Atlantic salmon (Salmo salar) in British Columbia, Canada. Aquaculture 162:69-77

Wallis GP, Beardmore JA (1984) An electrophoretic study of the systematic relationship of some closely related goby species (Pisces, Gobiidae). Biol J Linn Soc 22:107-123

Submitted: October 15, 2001; Accepted: January 24, 2002 Proofs received from author(s): April 29, 2002 